\title{
Implementation of EGA at the YLBMI Orphanage (Kampar District, Riau Province)
}

\author{
Vauzhea Sherlina ${ }^{1, *}$, Gryanda Wahyu Sugeng, Cika Tri Jayanti1, Fasckal Willman"1, \\ Bismi Annisa ${ }^{1}$
}

\author{
${ }^{1}$ Civil Engineering Study Program, Universitas Islam Riau, Jalan Kaharuddin Nasution Km. 11 No. 113, Pekanbaru, \\ Indonesia \\ *Corresponding authors.Email: vauzheasherli@gmail.com; annisa.bismi@gmail.com
}

\begin{abstract}
Approximately $60 \%-85 \%$ of the total volume of domestic clean water demand will be liquid gray water. Gray water is non-stick household wastewater in the form of waste originating from bathrooms, kitchens, and washing places. Based on the data obtained, at the YLBMI orphanage, the total clean water used every day is 1,474 liters/day. Gray water is discharged into sewers without being treated. One of the simple ways to treat gray water wastewater is by utilizing a plant biological process that can filter out the chemicals found in gray water. Ecotech Garden (EGA) is an innovation in treating gray water domestic waste and septic tank effluent using ornamental plants. So that it will be more effective if the liquid waste produced can be reprocessed, where the water discharged from gray water management contains high $\mathrm{N}$ and $\mathrm{P}$ elements. Based on this, water released from wastewater treatment will have a positive impact on plant growth. This water can be used for watering plants or gardens. Elemental Nitrogen can increase development and growth in plants, causing an increased number of leaves and elongation of roots in plants. This water can be used for watering plants or gardens. Elemental Nitrogen can increase development and growth in plants, causing an increase in the number of leaves and elongation of roots in plants. Based on this, the water discharged from wastewater treatment will have a positive impact on plant growth. This water can be used for watering plants or gardens.
\end{abstract}

Keywords: Clean water, Ecotech garden, garden, greywater, ornamental plan

\section{PRELIMINARY}

The high demand for water for the community and the limited availability of clean water causes serious problems for which alternatives must be found. Approximately $60 \%-85 \%$ of the total volume of clean water needs will be a domestic liquid waste [1]. Gray water is discharged into sewers without being treated. Services for green water processing in Indonesia are still limited, which is around $1.1 \%$. This service is only available in 11 big cities with centralized domestic wastewater treatment plants (IPAL) [2].

In most countries, regulations specific to wastewater reuse are relatively undeveloped, especially to the testing requirements for proposed treatment systems and associated water quality standards. Where guidelines/ standards do exist, they tend to focus exclusively upon conventional monitoring parameters such as microbial indicator organisms, organic content, turbidity/suspended solids and $\mathrm{pH}$, and do not specifically address significant micropollutants. [3].

Wastewater originating from households is divided into greywater and black water, based on its composition. The definition of gray water according to Lee, Edwin M (2017), and RMIT University (2008) is non-toilet household liquid waste in the form of waste 
originating from the bathroom (shower, bathtub, and sink), kitchen (sink/sink washing (machine washer). Gray water does not include wastewater from the toile and urinal. Liquid waste that comes from toilets and urine is black water (water containing human waste) which is channeled directly into the septic tank (septic tank) [4].

More greywater is produced in developing countries than is reported in developed countries. In the UK, the quantities of greywater and sewage produced are equal; in contrast, greywater represents $70-80 \%$ of domestic wastewater in Jordan and Oman. This might be due to the nature of living, environmental conditions such as weather, climate, and standard of living, social habits, and water usage patterns and time.

Countries such as Malaysia and Indonesia most often dispose of gray household water, and this occurs in village houses from the bathroom and kitchen openly together in the environment. As a result, these practices affect aquatic habitats, environmental aesthetics, plants, and soil because heavy metal concentrations are outside acceptable limits. Therefore, greywater must be properly treated before being discharged into water bodies.

Moreover, the accepted fact is that greywater should be treated with eco-friendly technology and without chemical additives or toxic by-products. Some authors indicated that the greywater might be subjected to a storage period before the treatment process; however, a storage period should be conducted for a short time to prevent microbial growth [5].

One of the simple ways to treat gray water wastewater is by utilizing a plant biological process that can filter out the chemicals found in gray water. Ecotech Garden (EGA) is an innovation in treating gray water domestic waste and septic tank effluent using ornamental plants. The characteristics of gray water wastewater have a relatively small organic load and relatively high nitrogen $(\mathrm{N})$ and phosphate $(\mathrm{P})$ elements. The wastewater treatment system through EGA can be implemented with a technology that is simple, practical, easy, and inexpensive to maintain [6].

EGA makes use of the construction of an artificial wetland constructed utilizing ecological technology to mimic conditions that occur in a natural wetland. The technology adopts special flora and fauna, soil, and microorganisms to remove pollutants of interest. Infiltration systems, both physical and biological processes remove solids; however, this review considers only physical removal of solids because that is the method adopted in most greywater treatment schemes. Filtration media could be in the form of sand, gravel, fine mesh, and many others [7].

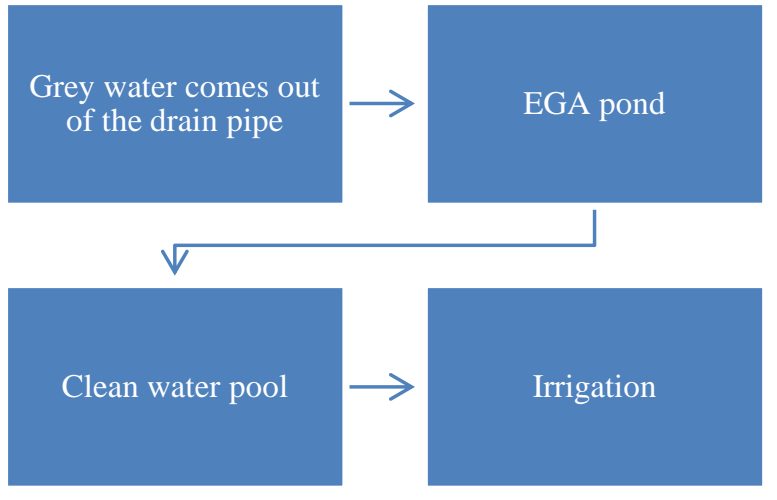

Figure 1 EGA Working System

The YLBMI Orphanage has 50 foster children with 2 administrators who will certainly produce large amounts of gray water waste every day. That liquid waste will be processed using Ecotech garden technology with the systems shown in Figure 1.

The gray water produced will be discharged into drainage through a drain pipe. The dam gate will be installed in the drainage so that the liquid waste stream will flow into the EGA pond through the pipe that has been installed. Gray water that has entered the EGA pool will be filtered through the sand and gravel at the bottom of the EGA pool. N \& P elements are absorbed by plants for growth, besides, EGA can reduce pollutants, such as : Biochemical Oxygen Demand (BOD), Chemical Oxygen Demand (COD), detergents, pathogenic bacteria (septic tank effluent), as well as deodorizing and purifying. water. The mechanism of absorption of pollutants in EGA through the plant root zone. This process increases oxygen more in the rhizosphere (plant roots). besides, there was also an increase in microorganisms, namely $\pm 10-100$ times more, because there is a channeling of oxygen from the leaves, this helps the absorption of pollutants from the treated wastewater. Wastewater BOD is lowered through oxidation and reduction processes (aerobic fermentation), while Ammonium ( $\mathrm{NH} 4 \mathrm{~N}$ ) is oxidized by autotrophic bacteria [8]

Water that comes out of the EGA, which has passed through biologically filtering, can be re-flowed to the ditch at the downstream part of the weir, or channeled into storage ponds and other water sources. Because the contaminants in the water have decreased, the water quality is better than the water quality before going through EGA. where the water discharged from gray water management contains high $\mathrm{N}$ and $\mathrm{P}$ elements. Elemental nitrogen can increase development and growth in plants, causing an increased number of leaves and elongation of roots in plants [9]. 
Table 1. Quality standards for the application of treated waste and recycled water in green space irrigation

\begin{tabular}{|l|c|c|}
\hline \multicolumn{1}{|c|}{ Parameter } & Unit & $\begin{array}{c}\text { Amount } \\
\text { allowed }\end{array}$ \\
\hline $\mathrm{pH}$ & - & $6.5-8.5$ \\
\hline $\mathrm{EC}$ & $\mathrm{s} / \mathrm{cm}$ & 700 \\
\hline Sodium Absorption Ratio & $\mathrm{Mg} / 1$ & 3 \\
\hline Sodium & $\mathrm{Mg} / 1$ & 70 \\
\hline Chloride & $\mathrm{Mg} / 1$ & 100 \\
\hline Boron & $\mathrm{Mg} / 1$ & 0.7 \\
\hline Carbonate & $\mathrm{Mg} / 1$ & 3 \\
\hline Bicarbonate & $\mathrm{Mg} / 1$ & 90 \\
\hline Phosphate & $\mathrm{Mg} / 1$ & 50 \\
\hline Nitrogen Nitrate & $\mathrm{Mg} / 1$ & - \\
\hline Nitrogen Ammonia & $\mathrm{Mg} / 1$ & 5 \\
\hline Source: & & \\
\hline
\end{tabular}

Source: [10]

Table 1 proposed quality standards for the application of treated waste and recycled water in green space irrigation. Based on this, the water discharged from wastewater treatment will have a positive impact on plant growth. This water can be used to water plants or gardens that will be managed by the orphanage, so that it can have a positive impact in the form of independent food products in the form of vegetables and fruit which can reduce expenditure on food purchases. Water can also be channeled into drums containing catfish which of course need clean water so that the catfish can survive and thrive.

At this time there has been an awareness that farming does not have to be in fields and rice fields. Public awareness to get fresh and healthy food ingredients, as well as reducing pollution and digestion of the surrounding environment so that a healthy lifestyle can be created in a healthy environment has presented the concept of Urban Farming. The concept of Urban Farming is a concept of forest farming, which is farming that is carried out and managed in the environment around houses and urban settlements. FAO defines urban agriculture as an industry that produces, processes, and markets vegetable products and foodstuffs, especially in response to the daily demands of urban consumers who apply intensive production methods, utilize and recycle urban resources and waste [10].
Based on the interests of partners (YLBMI Orphanage) besides being able to provide a positive impact in the form of liquid waste management, this can also be used as counseling for the orphanage children about the importance of saving water and how to manage the liquid waste they release every day.

So, it is very important to provide good handling of gray water waste. Reducing environmental pollution and turning waste treated water into a resource.

\section{METHOD}

\subsection{Preparation}

The preparatory stage includes determining the target location for the location, which is then followed by field observations, and making a letter of cooperation with partners.

\subsection{Data collection}

Data collection was carried out in 3 ways, namely; direct observation at the YLBMI orphanage and interviews with the orphanage before the Covid-19 pandemic, as well as by filling out a questionnaire via a google form.

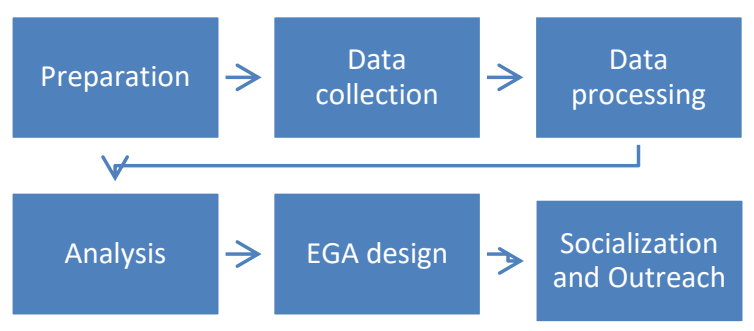

Figure 2. General stages of implementation

Table 2. Total use of clean water at the YLBMI orphanage

\begin{tabular}{|l|c|}
\hline \multicolumn{1}{|c|}{ information } & Volume (Liter) \\
\hline Shower (1 person) & $15 \mathrm{~L}$ \\
\hline Ablution (1 person) & $12 \mathrm{~L}$ \\
\hline Cook & $30 \mathrm{~L}$ \\
\hline Washing clothes & $20 \mathrm{~L}$ \\
\hline Wash the dishes & $20 \mathrm{~L}$ \\
\hline Total & 97 \\
\hline
\end{tabular}




\subsection{Data processing}

The data that has been obtained will be processed so that the total volume of liquid waste produced by the orphanage is obtained every day

According to these data, the volume of liquid waste produced by the YLBMI orphanage every day can be calculated, as follows:

Needs per individual (a):

bath + ablution $=15 \mathrm{~L}+12 \mathrm{~L}$

$$
=27 \mathrm{~L} / \text { person }
$$

The entire population of the nursing home (b):

$=$ Cooking + washing clothes + washing dishes

$$
\begin{aligned}
& =30 \mathrm{~L}+20 \mathrm{~L}+20 \mathrm{~L} . \\
& =70 \mathrm{~L} .
\end{aligned}
$$

The volume of clean water use, if the residents of the orphanage consist of 50 foster children and 2 caretakers of the orphanage.

$$
\begin{aligned}
& =(\text { ax number of residents in the orphanage })+b \\
& =(27 \mathrm{Lx} 52)+70 \mathrm{~L} \\
& =1.404 \mathrm{~L}+70 \mathrm{~L} . \\
& =1.474 \mathrm{~L} / \text { day }=1.474 \mathrm{~m}^{3} / \text { day }
\end{aligned}
$$

The volume of gray water waste produced by the YLBMI orphanage is 1,474 liters a day.

\subsection{Analysis}

The analysis is carried out by measuring whether the volume of waste generated every day can be accommodated in a previously designed liquid waste storage pool.

$$
\begin{aligned}
\mathrm{V} & =\text { area } \mathrm{x} \text { pool height } \\
& =(0.55 \mathrm{mx} 4 \mathrm{~m}) \times 0.85 \mathrm{~m} \\
& =1.87 \mathrm{~m}^{3}
\end{aligned}
$$

The EGA pond is considered capable of accommodating the volume of gray water wastewater, which is $1.87 \mathrm{~m}^{3}>1.474 \mathrm{~m}^{3}$

\section{EGA design}

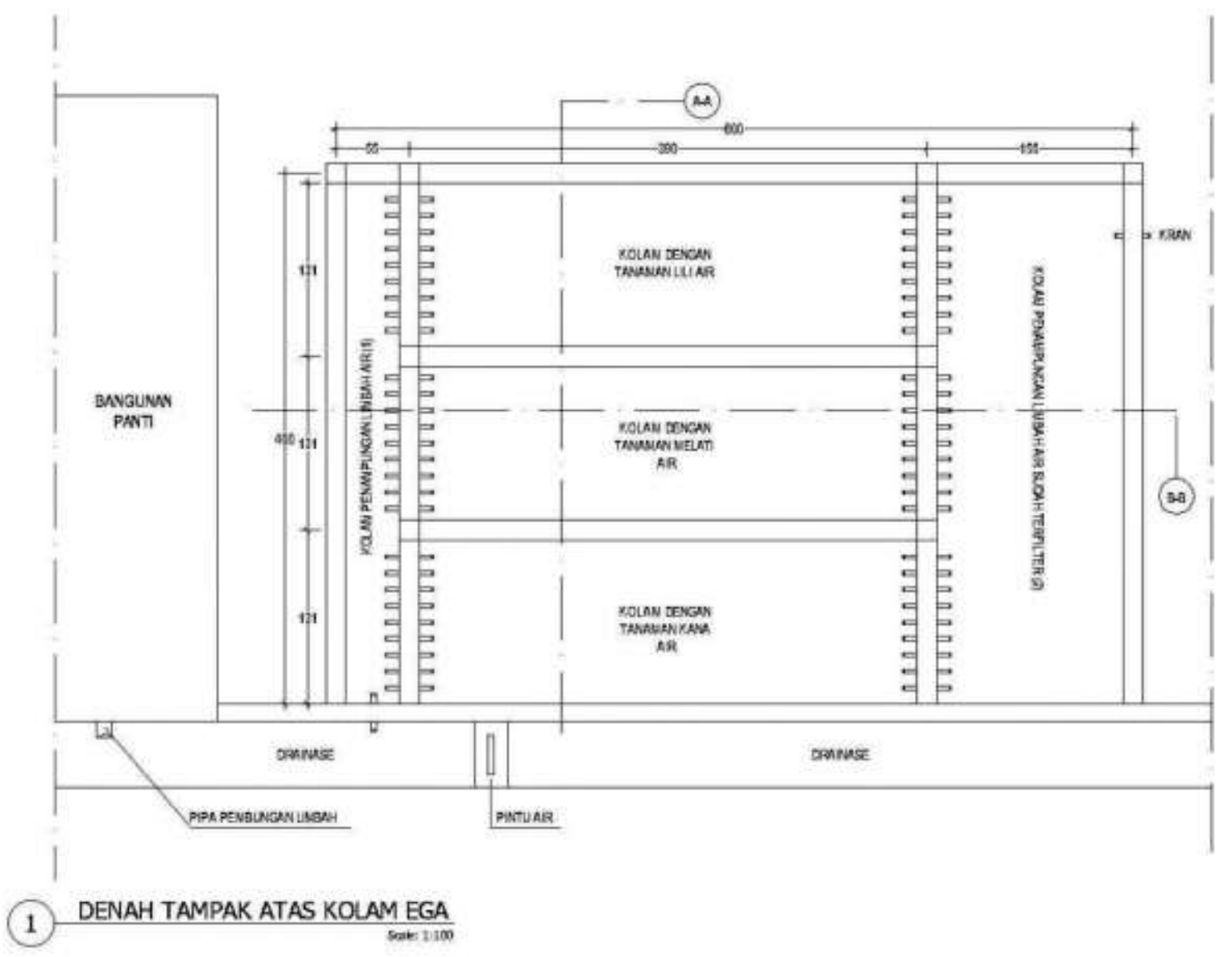

Figure 3. Plan view over the EGA pool 


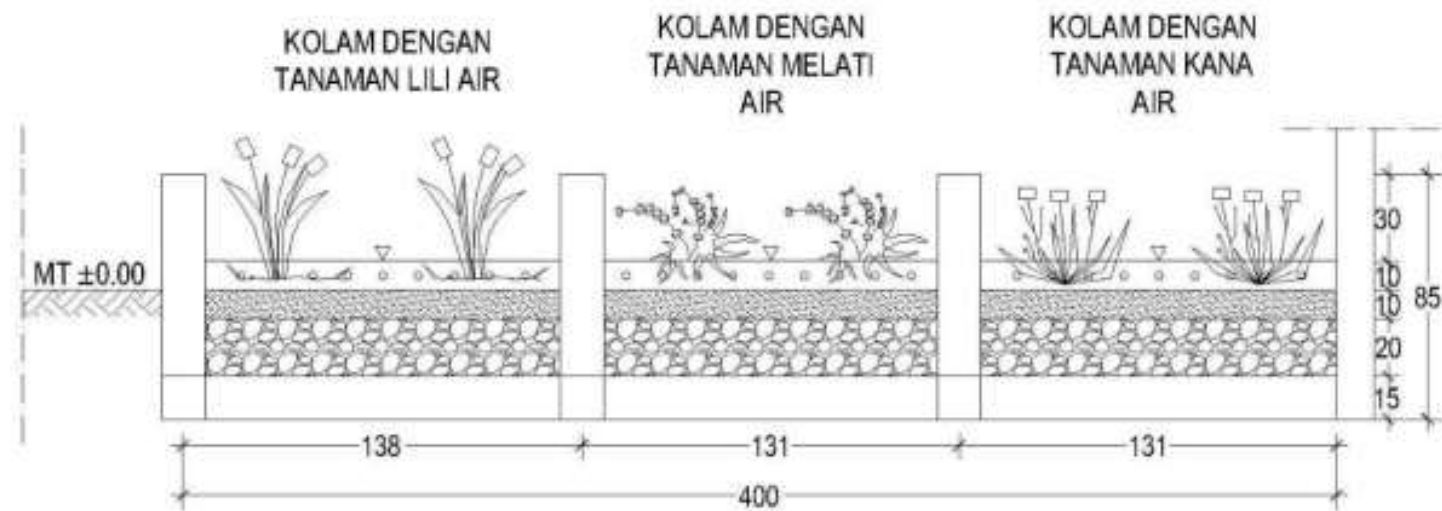

2

POTONGAN A-A

Figure 4. Piece A-A

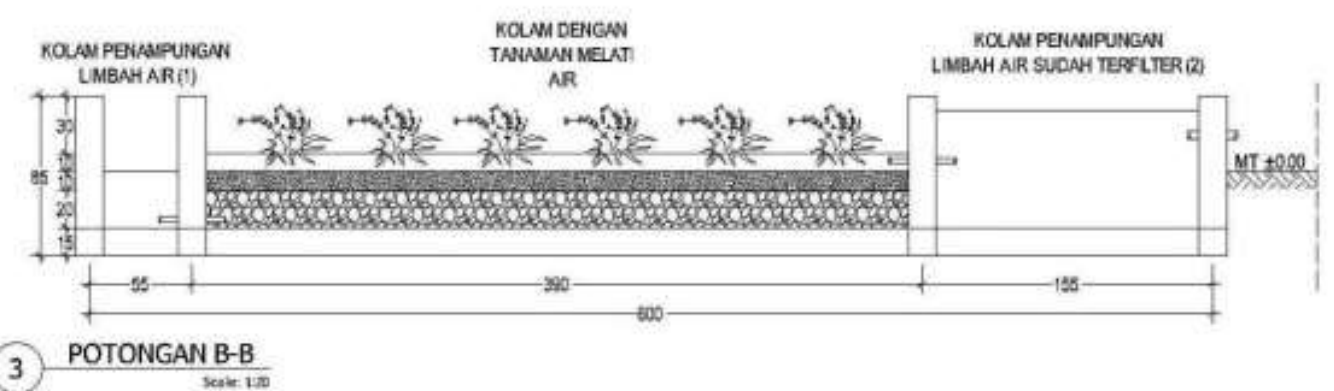

Figure 5. Piece B-B

\subsection{Socialization and Outreach}

Due to the current pandemic period, he can't carry out activities directly on site. Thus, there will be prior socialization regarding the stages of EGA development and an explanation of the work system. The activity was carried out four times with the help of the zoom meeting application as a means of communication.

\subsubsection{Tools and materials}

Table 3 Tools and Materials

\begin{tabular}{|l|l|}
\hline \multicolumn{1}{|c|}{ Tool } & material \\
\hline Hoe & Sand \\
\hline Bucket & gravel \\
\hline Cement Spoon & Cement (9 sacks) \\
\hline $\begin{array}{l}18 \text { "inch magnetic } \\
\text { water pass }\end{array}$ & Bricks (1250 pieces) \\
\hline Cart & 32mm pipe (2 pieces) \\
\hline Shovel & 26mm pipe (2 pieces) \\
\hline & Dam door \\
\hline
\end{tabular}




\subsubsection{EGA development phase}

The Development steps are:

a) Land clearing,

b) Excavation of the soil as deep as $45 \mathrm{~cm}$ using a hoe,

c) Blocking of the soil wall from the bottom of the excavation to $40 \mathrm{~cm}$ from the surface of the ground is done to avoid the collapse of the soil wall.

d) Putting gravel on the bottom of the pool with a thickness of $20 \mathrm{~cm}$ then putting sand on it with a thickness of $10 \mathrm{~cm}$,

e) Installing a $32 \mathrm{~mm}$ pipe for liquid waste flow to the pond. Installing a $26 \mathrm{~mm}$ diameter pipe at the bottom of the pond for the wastewater pool to the pond with ornamental plants, as well as a $26 \mathrm{~mm}$ diameter pipe at the limit of the water height for the ornamental plant pond to the water pond produced by EGA,

f) Planting ornamental plants in the form of water lilies, water jasmine, and water kana,

g) Installing the floodgates on the drainage so that water can turn and enter the EGA system,

\section{CONCLUSION}

1. Greywater wastewater can be reused for green land irrigation if it meets the specified standard values

2. Greywater liquid waste can be treated with a wetland system and a filtering process using sand, gravel, and ornamental plants.

3. The greywater wastewater from the YLBMI orphanage can be accommodated by a previously planned pool.

\section{ACKNOWLEDGMENTS}

The author would like to thank profusely to:

1) Service with a contract number " Number 02 / LL10 / SPKPKM / 2020 ".

2) Mrs. Dewi is the partner of the Muslim Bakti Foundation Orphanage who has been willing to be the object of implementing the Community Service PKM (PKM-M) activity.

3) All leaders of the Riau Islamic University.
4) Mrs. Bismi Annisa, ST., MT as the supervisor who provided time, energy, and thoughts to direct the author in the preparation of this manual.

\section{REFERENCES}

[1] E. Metcalf, Wastewater Engineering: Treatment, Disposal, and Reuse, Singapore: Mc Graw Hill Book Co., 2017.

[2] R\&D, EGA Ecotech Garden. https://litbang.pu.go.id/2016/06/30/ega-ecotechgarden/, 2016.

[3] E. Donner, E. Eriksson, DM Revitt, L. Scholes, HH Lützhøft, A. Ledin, "Presence and the Fate of Priority Substances in Domestic Greywater Treatment and Reuse Systems", Science of the Total Environment, 408(12) (2010) 2444-2451. DOI: https://doi.org/10.1016/j.scitotenv.2010.02.033

[4] M. LeeEdwin, San Francisco Graywater Design Manual for Outdoor Irrigation, San Francisco: Public Utility Commission, 2017.

[5] A.A. Wurochekke, R.M.S. Mohamed, A.A. AlGheethi, H. Atiku, H.M. Amir, H.M. MatiasPeralta, "Household Greywater Treatment Methods Using Natural Materials and Their Hybrid System", Journal of water and health, 14(6) (2016) 914-928. DOI: https://doi.org/10.2166/wh.2016.054

[6] P. Rintayati, Matsuri, H. Mahfud, The Application of Ecotech Garden to Facilitate Creative Household Liquid Waste Treatment for Residents in Jebres Surakarta Sub-District, SEMAR Journal, (2017) 2302-3937.

[7] M. Oteng-Peprah, M.A. Acheampong, N.K. deVries, "Greywater Characteristics, Treatment Systems, Reuse Strategies and User Perception a review", Water, Water, \& Soil Pollution, 229(8) (2018) 255. DOI: https://doi.org/10.1007/s11270018-3909-8

[8] A. Susanto, Water-friendly City Management through Water Metabolism City Approach to Support Sustainable City Development, 2018 
[9] E. Sari, Z. Aneloli, Suwirmen, "Effect of N fertilizer and drought stress on the growth and artemisinin content of the artemia Vulgaris plant", Andalas University biology journal (J.Bio.UA), (2018) 71-78.
[10] W. Janti, R. Selamet, T.A. Kuncoro, Organic House: Using Every Corner of the House to Plant Organic Vegetables, Jakarta: PT. AgroMedia Pustaka, 2015. 